\title{
EMLÉKÜLÉS KŐSZEGEN CHERNELHÁZI CHERNEL ISTVÁN SZÜLETÉSÉNEK 150. ÉVFORDULÓJA ALKALMÁVAL
}

\author{
Faragó Sándor \\ Soproni Egyetem, Vadgazdálkodási és Gerinces Állattani Intézet \\ University of Sopron, Institute of Wildlife Management and Vertebrate Zoology \\ H-9400 Sopron, Bajcsy-Zs u. 4., Hungary
}

\begin{abstract}
FARAGÓ S. (2019): COMMEMORATION OF THE $150^{\mathrm{TH}}$ ANNIVERSARY OF ISTVÁN CHERNEL'S BIRTH IN KÖSZEG. Hungarian Small Game Bulletin 14: 219-220. http://dx.doi.org/10.17243/mavk.2019.219

The Forestry Scientific Committee of the Hungarian Academy of Sciences, the Sub-committee of Wildlife Management, the University of West Hungary, the local government of the City of Köszeg together with the Örség National Park organized a remembrance session entitled „Profession Filled with Soul” at the Knights' Hall of the Jurisics-castle Cultural Centre in Köszeg (County Vas) on 30th November 2015. The event took place to the memory of chernelházi ISTVÁN CHERNEL, the 150th anniversary of his birth. The sitting was the repetition held at the Hungarian Academy of Sciences Budapest, because the organizers wanted to show the newest scientific results related to his life-work on the spot, where ISTVÁN CHERNEL was born, working and died.
\end{abstract}

KULCSZAVAK: CHERNEL ISTVÁN, emlékülés, Köszeg

KEY WORDS: ISTVÁN CHERNEL, commemoration, Kőszeg

A Magyar Tudományos Akadémia Erdészeti Tudományos Bizottsága, Vadgazdálkodási Albizottsága, a Nyugat-magyarországi Egyetem, Kőszeg Város Önkormányzata és az Örségi Nemzeti Park társrendezésében került megtartásra 2015. november 30-án, Kőszegen, a Jurisics-vár Művelődési Központ és Várszínház Lovagtermében a „Lélekkel teljesitett hivatás” című emlékülés, Chernelházi CHERNEL ISTVÁN születésének 150. évfordulója alkalmával.

Az ülés tulajdonképpen a Magyar Tudományos Akadémián megtartott emlékülés megismétlése volt azért, hogy a CHERNEL ISTVÁN születésének, müködésének és halálának színhelyén is bemutassuk az életmüvével kapcsolatos új tudományos eredményeket.

A konferencia levezető elnök: Prof. Dr. FARAGÓ SÁNDOR az akadémiai albizottság elnöke volt. Köszöntőt mondott MAJTHÉNYI LÁSZLÓ Vas megyei Közgyülés elnöke és HUBER LÁSZLÓ Köszeg város polgármestere. Az előadók sorban SÖPTEI IMRE, FARAGÓ SÁNDOR (1), HADARICS TIBOR, FARAGÓ SÁNDOR (2), BALOGH LAJOS és GYURÁCZ JÓZSEF voltak.

A konferencia zárása után Köszegen is bemutatásra került CHERNEL IsTVÁNNAL foglalkozó két könyv, - FARAGÓ SÁNDOR: Lélekkel teljesitett hivatás kétkötetes munkája, CHERNEL monográfiája, illetve MAJTHÉNYI LÁSZLÓ szerkesztésében $A$ vadászat nemes élvezete, címủ mü - válogatás CHERNEL ISTVÁN vadászati írásaiból és vadásznaplóiból.

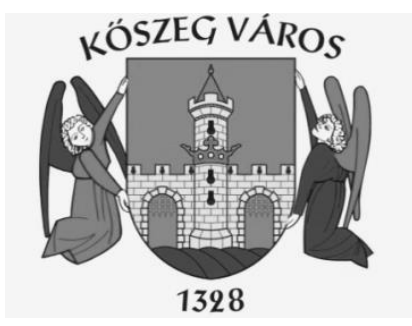



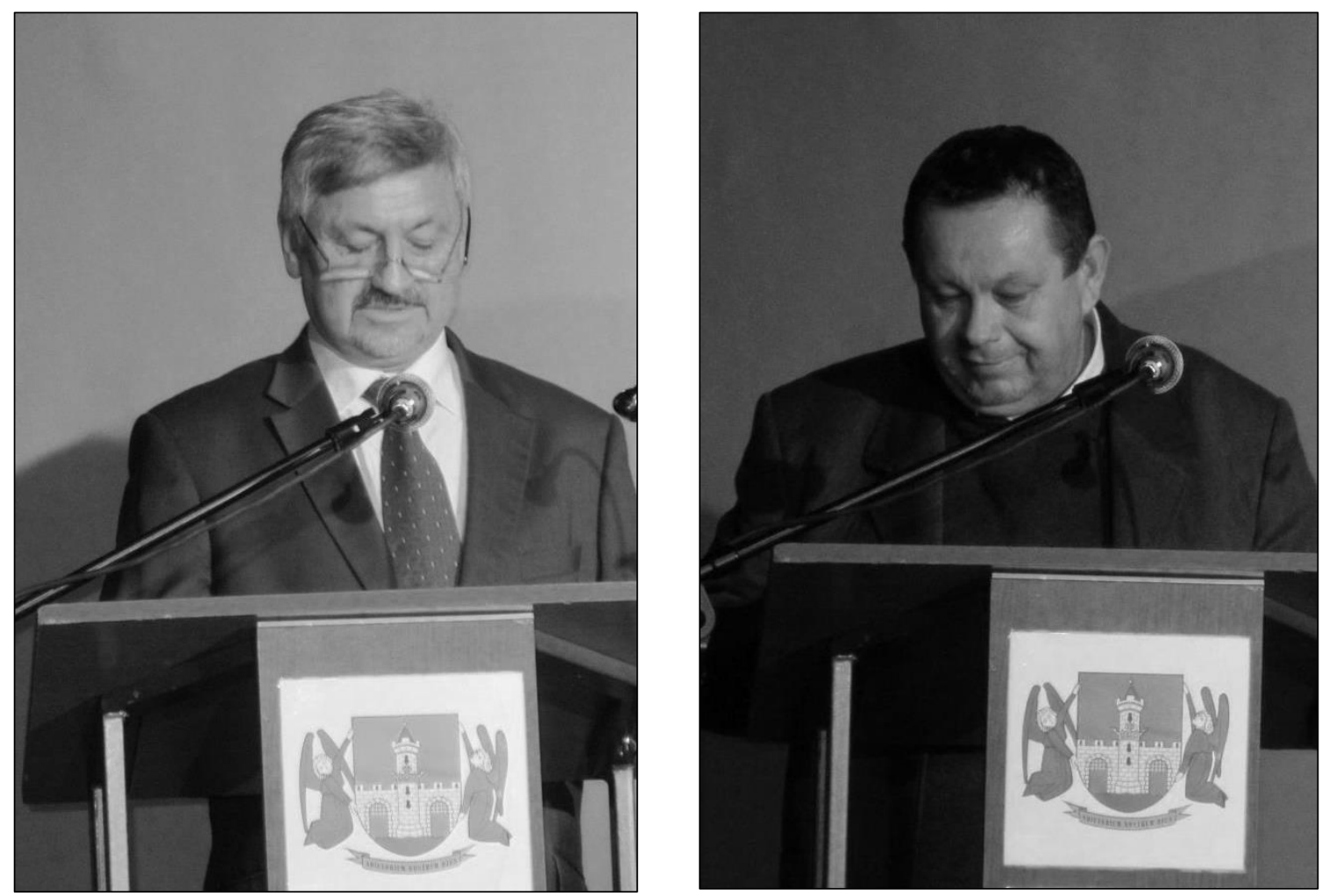

1. ábra: Köszöntő szavak - HUBER LÁSZLÓ Kőszeg polgármestere és MAJTHÉNYI LÁSzLó a Vas megyei Közgyülés elnöke (Fotó: FARAGó S.)

Figure 1: Word of welcome - LASZLÓ HUBER mayor of the City of Köszeg and LÁSZLÓ MAJTHÉNYI president of the General Assembly of the Vas County (Photo: S. FARAGÓ)
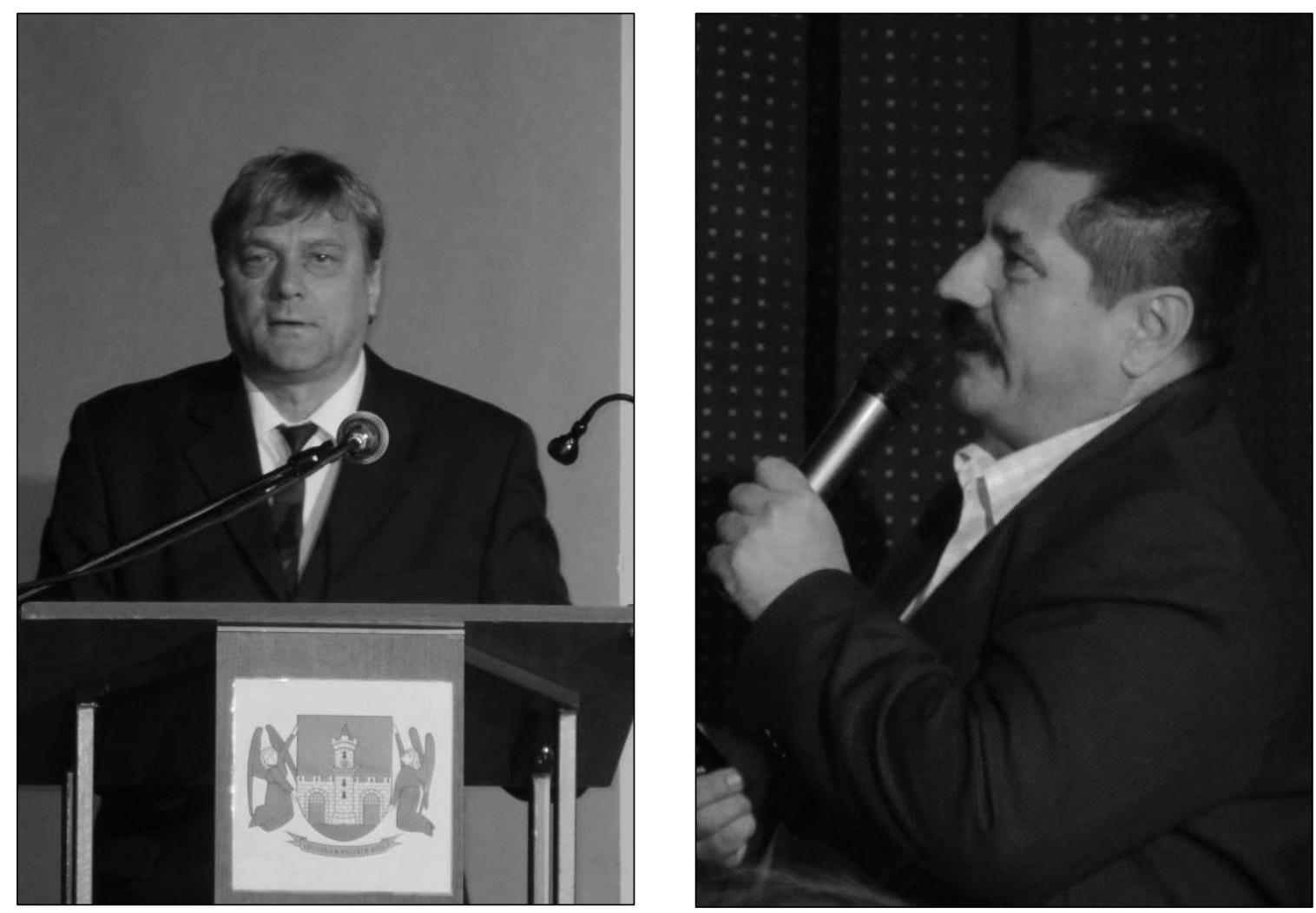

2. ábra: Előadók: SöPTEI IMRE És HADARICS TIBOR (Fotó: FARAGó S.)

Figure 2: Lecturers: IMRE SÖPTEI and TIBOR HADARICS (Photo: S. FARAGÓ) 